\title{
Epidemiological profile of farmworkers from the state of Rio de Janeiro
}

\author{
Perfil epidemiológico de trabalhadores rurais do estado do Rio de Janeiro \\ Perfil epidemiológico de trabajadores rurales del estado de Río de Janeiro
}

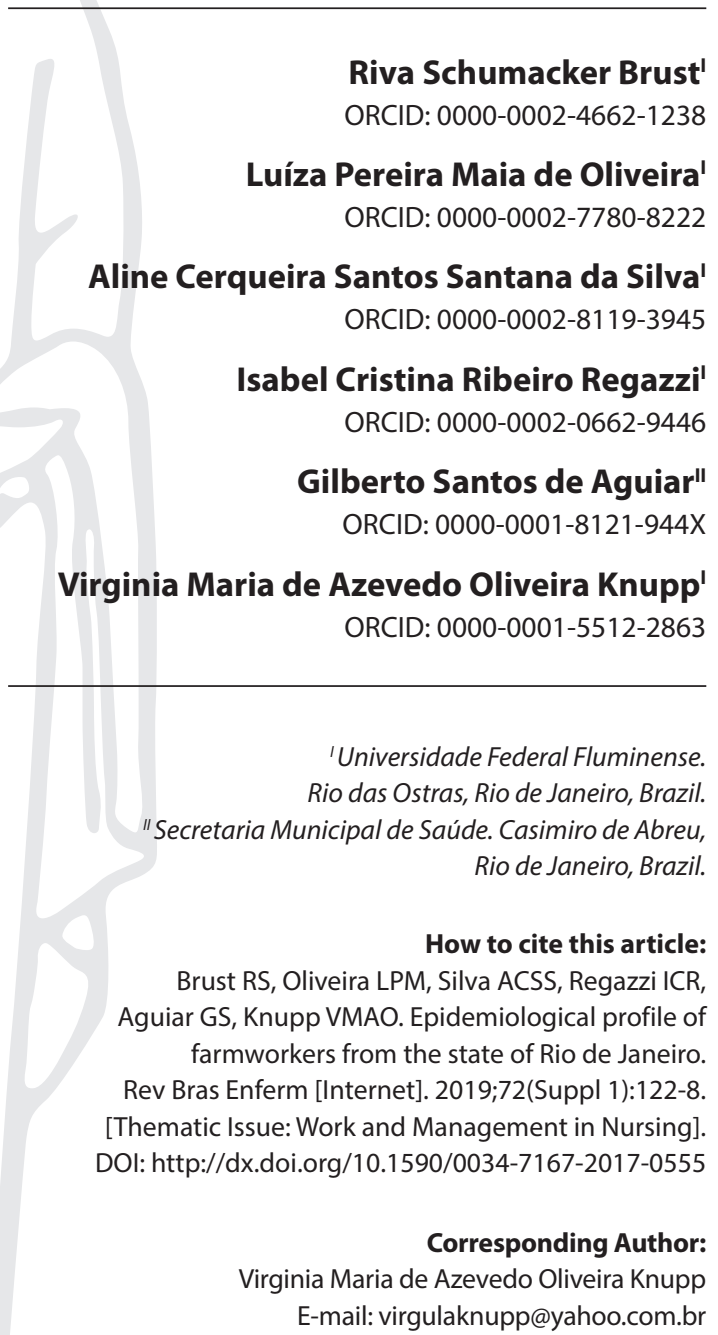

Submission: 08-04-2017

Approval: 02-07-2018

\section{ABSTRACT}

Objective: to describe the epidemiological profile of farmworkers exposed to pesticides in the city of Casimiro de Abreu, Rio de Janeiro State. Method: cross-sectional study, conducted through a questionnaire. The collected data were typed in spreadsheet and processed in the $\mathrm{R}$ software. Results: the predominance of female participants, between 40 and 60 years old, married, with some elementary education was observed. Furthermore, the family labor and the production for their own consumption and trade prevail. Herbicide is the most widely used pesticide. Most informants present poisoning symptoms, as they do not use Personal Protective Equipment nor sunscreen. Breast cancer is the most frequent in families; among the participants, $31 \%$ had hypertension and $6.4 \%$ diabetes. Conclusion: a population vulnerable to environmental and occupational risks, specially the middle-aged group and women, sets up a profile marked by regional differences.

Descriptors: Farmworkers; Occupational Exposure; Public Health; Occupational Nursing; Agriculture.

\section{RESUMO}

Objetivo: descrever o perfil epidemiológico dos trabalhadores rurais expostos a agrotóxicos no município de Casimiro de Abreu, estado do Rio de Janeiro. Método: estudo transversal, realizado por meio de questionário. Os dados coletados foram digitados em planilha eletrônica e processados no Programa R. Resultados: constatou-se predomínio de participantes do sexo feminino, entre quarenta e sessenta anos, casadas, com ensino fundamental incompleto. Ademais, prevalecem a mão de obra familiar e a produção para o próprio consumo e comércio. Herbicida é o agrotóxico mais utilizado. A maioria dos informantes apresenta sintoma de intoxicação, não utiliza Equipamento de Proteção Individual nem protetor solar. O câncer de mama é o mais frequente nas famílias; dentre os participantes identificaram-se $31 \%$ hipertensos e $6,4 \%$ diabéticos. Conclusão: uma população vulnerável aos riscos ambientais e ocupacionais, com destaque para o grupo de meia idade e do sexo feminino, configura um perfil marcado por diferenças regionais. Descritores: Trabalhadores Rurais; Exposição Ocupacional; Saúde Pública; Enfermagem do Trabalho; Agricultura.

\section{RESUMEN}

Objetivo: describir el perfil epidemiológico de los trabajadores rurales expuestos a agrotóxicos en el municipio de Casimiro de Abreu, estado de Río de Janeiro. Método: estudio transversal, realizado por medio de un cuestionario. Los datos recolectados fueron digitados en planilla electrónica y procesados en el Programa R. Resultados: se constató predominio de participantes del sexo femenino, entre cuarenta y sesenta años, casadas, con enseñanza fundamental incompleta. Además, prevalecen la mano de obra familiar y la producción para el propio consumo y comercio. Herbicida es el agrotóxico más utilizado. La mayoría de los informantes presenta un síntoma de intoxicación, no utiliza equipo de protección individual ni protector solar. El cáncer de mama es el más frecuente en las familias; de los participantes se identificaron un $31 \%$ hipertensos y un $6,4 \%$ diabéticos. Conclusión: una población vulnerable a los riesgos ambientales y ocupacionales, con destaque para el grupo de mediana edad y del sexo femenino, configura un perfil marcado por diferencias regionales.

Descriptores: Trabajadores Rurales; Exposición Ocupacional; Salud Pública; Enfermería del Trabajo; Agricultura. 


\section{INTRODUCTION}

Agriculture, since its appearance until now, went through numerous changes. The population growth demanded increase in food production, which contributed to the development of new planting and cultivation techniques ${ }^{(1-2)}$. The first scenario of transformation is the 16th-century Europe, where technical and scientific bases are fostered for a modern agriculture, increasing production ${ }^{(2)}$.

As the purpose was to innovate agriculture, making it the most productive, the United States, at the end of the 19th century, with political support and incentives, starts the "Green Revolution"(3), reform process that leverages the agricultural production. The goal was to increase productivity through modified seeds, use of pesticides and soil fertilization to reduce hunger in underdeveloped countries ${ }^{(4)}$.

In Brazil, the Green Revolution is introduced during the military period, between 1960 and 1970, bringing uncountable environmental and social impacts, for nature and for the health of farmworkers as well ${ }^{(3)}$. The overexploitation of soil caused depletion, increased water pollution, contamination of the environment and poisoning of farmers by pesticides, causing irreparable loss of biodiversity ${ }^{(5)}$.

Agriculture advanced quickly with technological innovation, through financial incentives. This progress was reflected negatively on small farmers who, without proper support and training, use pesticides indiscriminately to develop a more quick and plentiful crop. This innovation causes major environmental impacts, it deteriorates human health and requires public funding expenses with medical and hospital care ${ }^{(6)}$.

The use of pesticides grows every year in Brazil. In 2008, the country surpassed the United States and became the world's largest market ${ }^{(7)}$. In 2009, the pesticide consumption was 1 million tons, which is equivalent to an average consumption of $5.2 \mathrm{~kg}$ of agricultural poison per capita ${ }^{(8)}$. In 2010, the Brazilian market was responsible for consuming $19 \%$ of the global pesticide market ${ }^{(7)}$. Thus, the environmental contamination increased, raising the risk factors and vulnerability of the health of consumers and producers exposed to these kind of products.

According to data of the National Health Surveillance Agency and the Observatory of the Federal Industry from Paraná(9), during the II Seminar on Pesticide Market and Regulation, in 2012, Brazil was announced as the largest consumer of pesticides in 2008, with an increase of $190 \%$. With the increased use of pesticides, the number of cases of poisoning also increases, aggravated by the ease of obtaining those products without prescription. Also, improper use or non-use of equipment has damaged those who handle such products, as well as the environment and the final consumer. The information contained in labels and package inserts of any kind of pesticide is not clear and understandable, which hinders the correct handling of the product.

Most cases of food poisoning occurs for the reuse of packaging and the mishandling of products. Workers usually do not have information on the toxicity of the product and the importance of Personal Protective Equipment (PPE). This contributes to the increase of poisoning and consequently to the death of several farmworkers. According to data of the Brazilian National System of Toxic and Pharmacological Information (Sinitox), 99,035 cases of poisoning were recorded in Brazil in 2012, and 4,656 (4.7\%) of these were caused by pesticides, surpassing only medicines in general notifications. Of the total cases registered, 378 had death as outcome, of which 128 (33.86\%) cases were related to pesticides ${ }^{(10)}$.

Developing countries are the most affected, although there are specific laws for the sale of pesticides, which should be registered and sold only on prescription, prescribed by a qualified professional, as required by responsible bodies ${ }^{(11)}$. Unfortunately, the amount of professionals is small, the supervision is unstable and ineffective with all the clandestinity, which facilitates the acquisition of these products. In Brazil, the use of pesticides is governed by law No. 7,802 , of July 11,1989 , which provides for inspection, supervision, control, as well as other measures ${ }^{(12)}$. The Ministry of Agriculture, the Brazilian Institute of the Environment and Renewable Natural Resources (Ibama) and the National Sanitary Surveillance Agency (Anvisa) are responsible for registering these products.

\section{OBJECTIVE}

Describe the epidemiological profile of farmworkers exposed to pesticides in the city of Casimiro de Abreu, Rio de Janeiro State.

\section{METHOD}

\section{Ethical aspects}

This study was submitted to the Research Ethics Committee of the University Hospital Antônio Pedro (CEP-HUAP). Once approved, the researchers undertook to follow all the principles and norms pre-established by the CNS Resolution No. 466, of December 12,2012 , which regulates research involving human beings ${ }^{(13)}$.

\section{Design, location and period}

This is a quantitative, descriptive and cross-sectional study that examined the profile of the rural population exposed to pesticides in Varjão and Visconde, in the city of Casimiro de Abreu (RJ). The research scenario is located in Rio de Janeiro lowlands, which has 35 thousand inhabitants distributed into $451 \mathrm{~km}^{2}$. Agriculture accounts for only $0.4 \%$ of the municipal revenue but makes up $1 \%$ of the total collected with this activity throughout the state ${ }^{(14)}$.

In the city, family agriculture is predominant, with well-diversified activities in the properties. The production includes pineapple, pumpkin, cassava, rice, banana, sweet potato, coffee, sugar cane, citrus, eucalyptus, beans, cowpea, hay, greenery, yam, eggplant, orange, lemon, cackrey, corn, heart of palm, pasture, cucumber, bell pepper, pupunha, okra, tomatoes, green beans, in addition to cattle and hen farming, with production of eggs as well(15).

The number of 139 questionnaires were applied in the period of October and November 2016. Data were collected in the countryside of Casimiro de Abreu (Varjão and Visconde), where the rural workers lived, or in the fields.

\section{Population and sample; inclusion and exclusion criteria}

The study population was composed of 139 rural workers, of which 75 lived in Varjão and 64 in Visconde. The sample size was defined considering the limitation of time, cost and operational constraints. Initially, 150 participants were estimated based on the number of residents in the rural area of Casimiro de Abreu 
aged more than eighteen years. However, eleven people did not respond to the questionnaire. Locations in Varjão and Visconde were selected for presenting only the rural population and for having agriculture as their main livelihood and/or economic activity. The inclusion criterion considered the rural workers that lived in the locations studied. The exclusion criterion was the refusal in participating in the research.

The selection of variables was carried out with the aid of a professional of Occupational Health linked to the Municipal Health Secretariat of Casimiro de Abreu and through the literature. The following variables were selected: age, sex, race, marital status, education, use of pesticides, use of protective gear, episodes and frequency of headaches, the presence of allergy, use of sunscreen, eye irritation, family history of cancer, hypertension, diabetes, frequency of visits to the Basic Health Unit (BHU).

\section{Study protocol}

Data were collected through a questionnaire with seven openended and fifteen closed-ended questions. The participants were approached and oriented on the objectives of the survey, with balance of benefits and hazards, reading of the informed consent form (ICF) and request for the signature.

\section{Analysis of results and statistics}

The collected data were typed in spreadsheet and processed in the R software, which is free and allows the development of statistical calculations and graphical representations in an integrated way. Proportion and measures of central tendency were calculated, which make up the basic statistics. The results are presented in charts and tables.

\section{RESULTS}

The number of 139 rural workers were interviewed, of which $54.7 \%$ were women, $53.9 \%$ in the age group from 40 to 64 years (middle age), with a lower proportion of adolescents (3.6\%). Regarding marital status, we observed higher percentage of married farmworkers (40.3\%) and single people (36.7\%). For the variable race, $30.2 \%$ consider themselves white, while $23.7 \%$ are black and $46.1 \%$ are brown. In relation to education, $62.6 \%$ have some primary education and $9.3 \%$ are illiterate (Table 1 ).

Most of the workforce of the property belong to the family (95\%); only $3.6 \%$ of participants have employees; $2.2 \%$ reported having one employee; and 3.6\% did not report how many employees they have. As to the source of the family income, more than half of the people (69.1\%) live off their own production; $28.8 \%$ of respondents have other gains; $44.0 \%$ live off retirement pension; 4\% work as maids, and 4\% work as tractor drivers. Everything produced is used for personal consumption and trade. Most families have two members (27.3\%). The family income of farmworkers ranged from $R \$ 120$ reais to $R \$ 3$ thousand reais. The average income was a minimum wage (Table 2).

Regarding agricultural production, it is evident that the participants work with a diversified production, whose cultivation requires a lot of manpower. This diversification is a result of the reality experienced in Casimiro de Abreu, because the products are sold in street markets in the downtown city. Cassava is the most produced item, accounting for $24.4 \%$ of the total, followed by banana, with $16.7 \%$, and lemon, with $11.1 \%$ (Table 3 ).

Table 1 - Distribution of socioeconomic variables of farmworkers from Varjão and Visconde, Casimiro de Abreu, Rio de Janeiro, Brazil, 2016

\begin{tabular}{|c|c|c|}
\hline Variables & $\mathbf{n}$ & $\%$ \\
\hline \multicolumn{3}{|l|}{ Sex } \\
\hline female & 76 & 54.7 \\
\hline male & 63 & 45.3 \\
\hline \multicolumn{3}{|l|}{ Age (years) } \\
\hline up to 20 & 5 & 3.6 \\
\hline $20-39$ & 41 & 29.5 \\
\hline $40-64$ & 75 & 53.9 \\
\hline$>=65$ & 18 & 12.9 \\
\hline \multicolumn{3}{|l|}{ Marital status } \\
\hline Married & 56 & 40.3 \\
\hline Single & 51 & 36.7 \\
\hline Separated & 10 & 7.2 \\
\hline Cohabitation & 14 & 10.1 \\
\hline Widow & 7 & 5.0 \\
\hline Other & 1 & 0.7 \\
\hline \multicolumn{3}{|l|}{ Race } \\
\hline White & 42 & 30.2 \\
\hline Black & 33 & 23.7 \\
\hline Brown & 64 & 46.1 \\
\hline \multicolumn{3}{|l|}{ Education } \\
\hline Illiterate & 13 & 9.3 \\
\hline Elementary school & 15 & 10.8 \\
\hline Some elementary school & 87 & 62.6 \\
\hline High school & 14 & 10.1 \\
\hline Some high school & 10 & 7.2 \\
\hline
\end{tabular}

Table 2 - Distribution of socioeconomic variables related to the property and income of farmworkers from Varjão and Visconde, Casimiro de Abreu, Rio de Janeiro, Brazil, 2016

\begin{tabular}{lcc}
\hline Variables & $\mathbf{n}$ & $\%$ \\
\hline Variables Family labor & & \\
$\quad$ No & 5 & 3.6 \\
Yes & 132 & 95.0 \\
$\quad$ Not reported & 2 & 1.4 \\
Production income of the property & & \\
No & 40 & 28.8 \\
Yes & 96 & 69.1 \\
Not reported & 3 & 2.1 \\
Other income sources & & \\
$\quad$ Retirement pension & 11 & 44.0 \\
Family Bag allowance & 3 & 12.0 \\
Extra service & 3 & 12.0 \\
Public service & 2 & 8.0 \\
Bricklayer & 2 & 8.0 \\
Tractor driver & 1 & 4.0 \\
Maid & 1 & 4.0 \\
Employee & 1 & 4.0 \\
Person in charge of the farm & 1 & 4.0 \\
\hline
\end{tabular}


Table 3 - Percentage distribution of the production in the properties of farmworkers from Varjão and Visconde, Casimiro de Abreu, Rio de Janeiro, Brazil, 2016

\begin{tabular}{lcc}
\hline Products & $\mathbf{n}$ & $\%$ \\
\hline Cassava & 106 & 24.4 \\
Banana & 74 & 16.7 \\
Lemon & 51 & 11.1 \\
Corn & 38 & 9.3 \\
Greenery & 33 & 7.7 \\
Pineapple & 19 & 4.6 \\
Bell pepper & 12 & 2.8 \\
Orange & 8 & 1.6 \\
Tomato & 6 & 1.4 \\
Other & 85 & 20.4 \\
\hline
\end{tabular}

In relation to pesticides, $75 \%$ of respondents reported not using them, while $21 \%$ confirmed the use. Of these, each worker confirmed the use of one or more types of pesticides. We observed that the Round-up ${ }^{\circledR}$, herbicide comprised of glyphosate ammonium salt, is the most used pesticide (10\%) in the surveyed regions (Table 4).

Table 4 - Distribution by use of pesticides of farmworkers from Varjão and Visconde, Casimiro de Abreu, Rio de Janeiro, Brazil, 2016

\begin{tabular}{|c|c|c|}
\hline & $\mathbf{n}$ & $\%$ \\
\hline \multicolumn{3}{|l|}{ Use of pesticide } \\
\hline Yes & 29 & 21 \\
\hline No & 104 & 75 \\
\hline Not reported & 6 & 4 \\
\hline \multicolumn{3}{|l|}{ Pesticides used } \\
\hline Paraquat + round-up ${ }^{\circledast}$ & 1 & 0.7 \\
\hline Glyphosate & 2 & 1.4 \\
\hline Round-up ${ }^{\circledast}$ & 14 & 10 \\
\hline Vertimec + glyphosate & 1 & 0.7 \\
\hline Round-up ${ }^{\oplus}+$ glyphosate & 4 & 2.9 \\
\hline Round-up ${ }^{\oplus}+$ paradox & 1 & 0.7 \\
\hline Lepecid & 1 & 0.7 \\
\hline Paradox & 6 & 2.9 \\
\hline
\end{tabular}

Of the total respondents, $21.6 \%$ complain of headache, $15.1 \%$ had some type of skin rash and $18.7 \%$ had itchy eyes. When asked about the use of sunscreen, only $11.5 \%$ responded positively. Most rural workers (51.8\%) do not use any PPE at the time of application of the products, while $3.6 \%$ reported always using them (Table 5).

Table 5 - Distribution of health-related variables and individual protection of farmworkers from Varjão and Visconde, Casimiro de Abreu, Rio de Janeiro, Brazil, 2016

\begin{tabular}{lcc}
\hline Variables - Symptoms & $\mathbf{n}$ & $\%$ \\
\hline $\begin{array}{l}\text { Headache } \\
\text { Yes }\end{array}$ & 30 & \\
No & 109 & 21.6 \\
Skin rash & & 78.4 \\
Yes & 21 & \\
No & 118 & 15.1 \\
& & 84.9 \\
\hline
\end{tabular}

\begin{tabular}{|c|c|c|}
\hline Variables - Symptoms & $\mathbf{n}$ & $\%$ \\
\hline \multicolumn{3}{|l|}{ Itchy eyes } \\
\hline Yes & 26 & 18.7 \\
\hline No & 112 & 80.6 \\
\hline Individual protection & $\mathbf{n}$ & $\%$ \\
\hline \multicolumn{3}{|l|}{ Use of sunscreen } \\
\hline Yes & 16 & 11.5 \\
\hline No & 123 & 88.5 \\
\hline \multicolumn{3}{|l|}{ PPE } \\
\hline Sometimes & 10 & 7.2 \\
\hline Never & 72 & 51.8 \\
\hline Always & 5 & 3.6 \\
\hline Not reported & 52 & 37.4 \\
\hline Health-related & $\mathbf{n}$ & $\%$ \\
\hline \multicolumn{3}{|l|}{ Cancer in the family } \\
\hline Yes & 21 & 15.1 \\
\hline No & 118 & 85.9 \\
\hline \multicolumn{3}{|l|}{ Diabetes } \\
\hline Yes & 9 & 6.4 \\
\hline No & 130 & 93.6 \\
\hline \multicolumn{3}{|l|}{ Hypertension } \\
\hline Yes & 43 & 31.0 \\
\hline No & 96 & 69.0 \\
\hline \multicolumn{3}{|l|}{ Basic Health Unit } \\
\hline Sometimes & 96 & 69.1 \\
\hline Never & 14 & 10.1 \\
\hline Always & 29 & 20.8 \\
\hline
\end{tabular}

Note: PPE - Personal Protective Equipment.

As for the history of cancer, $15.1 \%$ of them claimed to have cases of the disease in the family, of which $20.7 \%$ reported breast cancer, $17.2 \%$ prostate cancer and $7.1 \%$ skin cancer. The most affected people were uncles, mom, dad and the respondent $\mathrm{him} /$ herself. The number of hypertension and diabetes among the rural workers was $31 \%$ and $6.4 \%$, respectively. In the analysis of the frequency with which they visit UBS, 20.8\% attend often and $10.1 \%$ answered that never went to the local UBS (Table 5).

\section{DISCUSSION}

The predominance of the female worker in the rural environment deserves attention, because in several studies there is a male predominance. Martins et al. ${ }^{(16)}$ reported the greatest amount of men in almost all the 48 people interviewed in their research, in which the male population was $97.9 \%$. However, Jalil ${ }^{(17)}$ points out that women's participation has been great in the context of family agriculture. The reason why these women do not appear in the statistics is the lack of documentation; they represent almost $40 \%$ of rural workers, and of this total, $60 \%$ of them do not have access to public policies, living in precarious conditions. In the city of Araçuaí, in the Mesoregion of Jequitinhonha, Minas Gerais, women have been strengthening local agriculture and their economic autonomy, their insertion in rural areas ${ }^{(18)}$.

Data with the highest number of middle-aged workers (from 40 to 64 years) corroborate those presented in the literature. The research carried out by Valdez et al. ${ }^{(19)}$ points out that 40 
respondents (18\%) are aged between 31 and 50 years, and $35.71 \%$ are 18 and 30 years. The result of this study is in line with the statistical data of Brazil, which, in 2009, presented the largest number of rural workers in the age group from 40 to 59 years.

The variable marital status is related to the social support network, which directly involves family health care. The support, the care received by a family member, is beneficial and motivating. Support networks are also important in combating certain diseases and in developing strategies to improve the quality of life, strengthen relations and preserve bonds ${ }^{(20)}$.

Race is self-reported and considered a proxy of socioeconomic condition. This study encompass a greater number of brown people. It is clear that Browns and Blacks have a different and inferior condition regarding the access to goods, services and opportunities, compared with white people ${ }^{(21)}$. They are discriminated economically and survive on incomes smaller or equal to a minimum wage; they are illiterate or have not completed the study and work in subordinate and/or underappreciated positions by society.

Education levels were low among respondents, most had some elementary education. This situation has serious implications on the lives of workers, because, by not knowing how to read or not being able to understand the terms used in the packaging of pesticides, they do not realize the actual severity of products, aggravated by the lack of training and guidance from a qualified professional. Vasconcelos et al. ${ }^{(19)}$ found results equivalent to those presented in this study. The authors found that most farmworkers have low educational level and stated that this aspect directly affected the access to information, as described herein, in addition to interfering negatively their perception of health.

Round-up ${ }^{\circledR}$ was the most used pesticide in the agricultural regions surveyed. This product is mildly toxic and dangerous to the environment. Round-up ${ }^{\circledR}$ is a desiccant applied before the sowing or planting of seedlings; it kills weeds, preventing some species to weaken the crop. Herbicides are the most commercialized chemicals and the ones that have obtained the greatest increase in the percentage of imports ${ }^{(22)}$. The findings of this study are also in accordance with the research made in Paraná, state where the herbicide was the most used in $2009^{(23)}$.

The confirmation of glyphosate as a carcinogen is still a subject for extensive discussion. The International Agency for Research on Cancer (larc) classified this herbicide as "possibly carcinogenic to humans"(24). However, seven out of twelve studies in rats found growth of malignant tumor ${ }^{(25)}$. An integrative review about pesticides and non-Hodgkin's lymphoma was found association between glyphosate and this type of cancer ${ }^{(26)}$.

It is very common that people who deal with pesticides, both in the preparation and in handling, end up having symptoms, such as headache, skin rash, itchy eyes, among others. Agrochemical poisoning may occur, and, many times, the employee does not even realize that it comes from this practice. The use of the product can reach other people, such as consumers of the food contaminated with residues, but unfortunately the farmworkers themselves are the most affected by health problems ${ }^{(27)}$.

In this study, the proportion of rural workers not using PPE was high, compromising the security of their labor activity. A similar result was observed in the survey conducted in five cities in the northwestern region of Rio Grande do Sul, where only $1.4 \%$ of rural workers use PPE ${ }^{(28)}$. Siqueira et al. ${ }^{(29)}$ observed a similar reality in the city of Vitória de Santo Antão, Pernambuco, where few workers use PPE.

A portion of the respondents claims some type of cancer in the family. It is known the use of pesticide predisposes individuals to developing certain cancers. According to Inca ${ }^{(30)}$, every year the number of cases of the disease grows in Brazil, especially among workers exposed to the sun, with emphasis on skin cancer, whose main risk factor is too much sun exposure. Although the sample for skin cancer was small among our interviewees, we highlight the concern with the occupational hazard, as well as the way the employee experiences the disease and the treatment and/or protection methods, since most of them do not use sunscreen.

The proportion of diabetic and hypertensive rural workers was small, but it is possible that the poisoning symptoms mask the diagnosis of these diseases. Therefore, it is necessary to increase the frequency of workers' visits to UBS and make the appropriate diagnostic methods available, such as the measurement of blood pressure and fasting capillary blood glucose.

\section{Limitations of the study}

This study presents some limitations regarding the discussion of results due to the absence of recent publications on the topic studied.

\section{Contributions to the field of nursing, health or public policy}

To learn the epidemiological profile of the rural worker will develop a nursing practice based on the individual vulnerable to several occupational risk factors within the environment of care.

\section{CONCLUSION}

We conclude that the epidemiological profile of farmworkers exposed to pesticides in the city of Casimiro de Abreu (RJ) is marked by vulnerability to environmental and occupational risks, with emphasis on the population group from 40 to 64 years and women, establishing a profile marked by regional differences. The rural area is gradually distant from the urban area due to voids in relation to health, education and occupation in this group and in those that coexist in this environment of care.

To learn the epidemiological profile of this population allowed us to understand the difficulties experienced by a group exposed to environmental and socioeconomic hazards, which interfere negatively on the health of these people. In addition, we observed how small rural workers are affected by the lack of information on agrochemicals, health care and health services.

The results obtained in relation to the use of pesticides require a careful analysis and further studies, since the lack of publication on the subject in current journals was the limitation of this study. The health of farmworkers deserves prominence in public policies, especially those related to the small producer, with emphasis on health promotion and prevention of diseases. 


\section{REFERENCES}

1. Pontifícia Universidade Católica de São Paulo (PUC). Boletim de Inovação e Sustentabilidade (BISUS). Desmatamento. Salles MFA \& Guevara AJH. BISUS; 2(1); 2013.

2. Delgado GC, Bergamasco SMPP. Agricultura familiar brasileira: desafios e perspectivas de futuro. Brasília: Ministério do Desenvolvimento Agrário [Internet]. Brasília: Ministério do Desenvolvimento Agrário; 2017 [cited 2018 Jan 25]. 470 p. Available from: http://www.mda.gov.br/ sitemda/sites/sitemda/files/user_img_1756/Agricultura\%20Familiar_WEB_LEVE.pdf

3. Romaniello MM, de Paula Assis TR. Extensão rural e sustentabilidade: guia de estudos [Internet]. Lavras (MG): UFLA; 2015 [cited 2018 Jan 25] 114 p. Available from: https://edisciplinas.usp.br/pluginfile.php/4128960/mod_resource/content/0/Extens\%C3\%A3o-rural-Esutentabilidade\%20\%281\%29.pdf

4. Vargas GA. A Economia da soja: vantagens e desvantagens da transgenia no Brasil [Monograph on the Internet]. ljuí (RS): Universidade Regional do Nordeste do Estad do Rio Grande do Sul, Departamento de Ciências Administrativas, Contábeis, Econômicas e da Comunicação, Curso de Graduação em Ciências Econômicas; 2013 [cited 2018 Aug 26] 68 p. Available from: http://bibliodigital.unijui.edu. br:8080/xmlui/bitstream/handle/123456789/2023/Gisele\%20Vargas.pdf?sequence=1

5. Clemente, EC. A agricultura familiar e a questão da sustentabilidade: alguns pontos para o debate. Ateliê Geogr [Internet]. 2015 [cited 2018 Jan 10];9(3):88-108. Available from: http://repositorio.bc.ufg.br/xmlui/bitstream/handle/ri/11172/Artigo\%20-\%20Evandro\%20 C\%C3\%A9sar\%20Clemente\%20-202015.pdf?sequence=1\&isAllowed $=y$

6. Carneiro FF, Rigotto RM, Augusto LGS, Búrigo AC, editors. Dossiê ABRASCO: um alerta sobre os impactos dos agrotóxicos na saúde [Internet]. Rio de Janeiro: EPSJV; São Paulo: Expressão Popular. 2015 [cited 2018 Jan 24]. 624 p. Available from: https://11-\%20Dossiê20 Abrasco\%20-\%20um\%20alerta\%20sobre\%20os\%20impactos\%20dos\%20agrotóxicos\%20na\%20saúde.pdf

7. INCA: Instituto Nacional de Câncer José Alencar Gomes da Silva [Internet]. Rio de Janeiro: INCA, 2015. Brasil lidera o ranking de consumo de agrotóxicos. 2015 [cited 2018 Jan 24]; [about 1 screen]. Available from: http://www2.inca.gov.br/wps/wcm/connect/ comunicacaoinformacao/site/home/namidia/brasil_lidera_ranking_consumo_agrotoxicos

8. INCA: Instituto Nacional de Câncer José Alencar Gomes da Silva. Posicionamento do Instituto Nacional de Câncer José Alencar Gomes da Silva acerca dos agrotóxicos [Internet]. Rio de Janeiro: Inca; 2015[cited 2018 Aug 13]. Available from: http://www1.inca.gov.br/inca/ Arquivos/comunicacao/posicionamento_do_inca_sobre_os_agrotoxicos_06_abr_15.pdf

9. Pelaez V. Mercado de agrotóxico e regulação. Anais do Seminário Mercado de Agrotóxico e Regulação; 2012. Brasília: Observatório da Indústria de Agrotóxicos da Anvisa; 2012.

10. Oliveira KM, Lucchese G. [Sanitary controlo of pesticides in Brazil: the case of methamidophos]. Rev Tempus Actas de Saúde Col [Internet]. 2013[cited 2018 Aug 9];7(1):211-24. Available from: http://www.tempusactas.unb.br/index.php/tempus/article/view/1289 Portuguese.

11. Gouveia EC, Ferreira HS, Mello MVFA, Cárdenas AM, Silva SR. [Epidemiological profile of Timber Channel's workers from an Amazon River Basin]. PRACS [Internet]. 2014[cited 2018 Aug 9];7(1):49-60. Available from: https://periodicos.unifap.br/index.php/pracs/article/view/799/ Gouveiav7n1.pdf Portuguese.

12. Presidência da República (BR), Casa Civil, Subchefia para Assuntos Jurídicos. Lei 7.802 de 11 de julho de 1989. Dispõe sobre a pesquisa, a experimentação, a produção, a embalagem e rotulagem, o transporte, o armazenamento, a comercialização, a propaganda comercial, a utilização, a importação, a exportação, o destino final dos resíduos e embalagens, o registro, a classificação, o controle, a inspeção e a fiscalização de agrotóxicos, seus componentes e afins, e dá outras providências. Diário Oficial da União: República Federativa do Brasil. 1989. Jul 12; Seção 1:60 (col. 3).

13. Ministério da Saúde (BR), Conselho Nacional de Saúde. Resolução no 466 de 12 de dezembro de 2012. Regulamenta a pesquisa envolvendo seres humanos. Diário Oficial da União: República Federativa do Brasil, 2012. Jun 13; Seção 1:59 (col. 3).

14. IBGE: Instituto Brasileiro de Geografia e Estatística. Cidades. Rio de Janeiro: IBGE; c2017. Panorama: população [Internet]. c2017 [cited 2018 Jun 12]. Available from: https://cidades.ibge.gov.br/v4/brasil/rj/casimiro-de-abreu/panorama

15. Aguiar GS, Motta SD, de Sousa RG, Alvim RG, Penetho OS, Gaspar A, Campos GS, Proença LA, Siqueira JD, Souza Na, Porto JRS, de Castro SO, Mello MSC. A experiência da Secretaria Municipal de Saúde de Casimiro de Abreu (RJ) na busca de soluções para intoxicações e mortes por agrotóxicos em trabalhadores da agricultura. [Poster on the Internet]. In: 2 Simpósio Brasileiro de Saúde \& Ambiente; Belo Horizonte (MG): Sibsa; 2014 Out 19-22 [cited 2018 Abr 12]. Available from: http://www.sibsa.com.br/resources/anais/4/1404176919_arquivo_Resumo_ CasimiroSIBSA.pdf

16. Martins SKM, Cerqueira SG, Sampaio AMA, Lopes AA, Freitas MR. Exposição ocupacional aos agrotóxicos: um estudo transversal. Rev Inter Toxicol Risco Amb Soc [Internet]. 2012 [cited 2018 Aug 30];5(3):6-27. Available from: http://www.revistarevinter.com.br/autores/index.php/ toxicologia/article/view/131/347

17. Jalil L. Soberania alimentar, feminismo e ação política: um olhar sobre as ações do movimento de mulheres camponesas. Agriculturas [Internet] 2009 [cited2018 Aug 30];6(4):9-11. Available from: http://docs12.minhateca.com.br/992856851,BR,0,0,Agriculturas_v6n4.pdf

18. Pastório TI, Roesler BVRM. O papel da mulher no processo produtivo familiar com sustentabilidade [Internet]. In: 6 seminário Nacional Estado e Políticas Sociais, 2 seminário de Direitos Humanos. Unioeste: Campos dos Toletos (PR); 2014 [cited 2018 Aug 31]. 10 p. Available from: http://cacphp.unioeste.br/eventos/Anais/servicosocial/anais/ 
Epidemiological profile of farmworkers from the state of Rio de Janeiro Brust RS, Oliveira LPM, Silva ACSS, Regazzi ICR, Aguiar GS, Knupp VMAO.

\section{TC_PAPEL_MULHER_PROCES_PRODUT_FAMILIAR_COM_SUSTENTABILIDADE.pdf}

19. Vasconcellos MV, Freitas CF, Silveira CA. Caracterização do uso de agrotóxicos entre trabalhadores rurais. [Internet]. 2014 [cited 2018 Aug 30];40(2): 87-96. Available from: https://periodicos.ufsm.br/revistasaude/article/download/11934/pdf

20. Pinto NMA, Pontes FAR, Silva SSC. A rede de apoio social e o papel da mulher na geração de ocupação e renda no meio rural. Temas Psicol [Internet]. 2013. [cited 2018 Aug 30];21(2): 297-315. Available from: http://pepsic.bvsalud.org/scielo. php?script=sci_arttext\&pid=S1413-389X2013000200001\&lng=pt

21. Wallace AS, Janaína SC, Rafaela MGC. Pluriatividade e discriminação salarial por gênero e raça no mercado de trabalho rural brasileiro. Rev Espacios [Internet]. 2016 [cited 2018 Jan 25]; 37(22). Available from: http://www.revistaespacios.com/a16v37n22/16372221.html

22. IBAMA: Instituto Brasileiro do Meio Ambiente e dos Recursos Naturais Renováveis. Brasília: Ministério do Meio Ambiente, 2016. Boletim Anual de Produção, Importação, Exploração e vendas de Agrotóxicos no Brasil [Internet]. 2013 [cited 20181 Aug 31]. Available from: http:// www.ibama.gov.br/agrotoxicos/relatorios-de-comercializacao-de-agrotoxicos\#boletinsanuais

23. Secretaria do Estado da Saúde do Paraná. Vigilância da Saúde de Populações Expostas a Agrotóxicos no Paraná. [Internet]. 2013 [cited 2018 Aug 31]. Available from: http://portalarquivos.saude.gov.br/images/pdf/2015/setembro/02/PLano-PR.

24. International Agency for Research on Cancer. IARC Monographs Volume 112: evaluation of five organophosphate insecticides and herbicides [Internet]. Lyon: World Health Organization; 2015[cited 2018 Aug 13]. Available from: http://www.iarc.fr/en/media-centre/ iarcnews/pdf/MonographVolume112.pdf

25. Clausinglis $\mathrm{P}$, Robinson C, Burtscher-Schaden $\mathrm{H}$, editors. Glyphosate and cancer: authorities systematically breach regulation [Internet]. Austria: Global 2000; 2017 [cited 2018 Aug 31]. Available from: https://www.stopogm.net/sites/stopogm.net/files/repo/ glifosatorelatorioportugues2017.pdf

26. Costa VIB, Mello MSC, Friedrich K. Exposição ambiental e ocupacional a agrotóxicos e o linfoma não Hodgkin. Saúde Debate [Internet]. 2017;41 (112):49-62. Available from: http://www.redalyc.org/pdf/4063/406350708006.pdf

27. Bohner TOL. Agrotóxicos e sustentabilidade: percepção dos sujeitos sociais no meio rural [Dissertation on the internet]. Rio Grande do Sul: Universidade Federal de Santa Maria, Centro de Ciências Rurais; 2015 [cited 2018 Aug 31]. 103 p. Available from: http://w3.ufsm.br/ppgexr/ images/dissertacoes/Disserta\%C3\%A7\%C3\%A3o_TANNY_OLIVEIRA_LIMA_BOHNER.pdf

28. Lima FO, Montagner GFFS, Bezerra AS, Reinehr CV, Bellinaso ML. Exposição a agrotóxicos e radiação UV como fatores de risco ao trabalhador rural. Rev Contexto Saúde [Internet]. 2013 [cited 2018 Jan 24]. Available from: https://revistas.unijui.edu.br/index.php/contextoesaude/ article/view/2982/3352

29. Siqueira DF, Moura RM, Laurentino GEC, Araújo AJ, Cruz SL. Análise da Exposição de trabalhadores a agrotóxicos. Rev Bras Promoc Saúde [Internet]. 2013 [cited 2018 Jan26]; 26(2): 182-191. Available from: http://www.redalyc.org/html/408/40828920005/

30. INCA: Instituto Nacional de Câncer José Alencar Gomes da Silva. Rio de Janeiro: INCA, 2016. Estimativa 2016: incidência de câncer no Brasil [Internet]. 2015 [cited 2018 Jan 26].Available from: http://www.inca.gov.br/estimativa/2016/estimativa-2016-v11.pdf 